\title{
Lost in Contrasted Strands of Dislocated Identity: A Study of Two Diasporic Characters, Tha'mma and Ila in Amitav Ghosh's The Shadow Lines
}

\author{
UMME KULSUM \\ NAHID KAISER
}

'Once you start moving you never stop'

(The Shadow Lines L 215 )

Diaspora, in other words, the movement (be it voluntary or forcible) of people from homeland to new lands is one of the major by-products of the process of colonization. Colonialism breeds diaspora by involving temporary or permanent dispersion and settlement of people over the entire world, and thereby, it nourishes the dislocation and unsettlement. According to Wikipedia, in the beginning the term diaspora was used by the ancient Greeks to refer to the citizens of a grand city who migrated to a conquered land with the purpose of colonization to assimilate the territory into the empire. The original meaning was cut off from the present meaning when the Old Testament was translated into Greek. The word diaspora was used to refer specifically to the populations of the Jews exiled from Judea in 586 BC the Babylonians and Jerusalem in AD136 by the Roman Empire. The term was assimilated from Greek into English in the late $20^{\text {th }}$ century. The twentieth century continued to see massive ethnic refugee crises, due to war and the rise of nationalism, fascism, communism, and racism as well as from natural disasters and economic collapse. As Homi Bhabha says in 'Location of Culture' anthologized in Literary Theory: An Anthology, 
" For the demography of the new internationalism is the history of postcolonial migration, the narratives of cultural and political Diaspora, the major displacements of peasant and aboriginal communities, the poetics of exile, the grim prose of political and economic refugees"'(936).

The theme of diaspora has drawn the attention of post-colonial writers from the decolonized lands. Particularly, contemporary subcontinental writers are keenly concerned with this inevitable offspring of colonialism. In much of the literature there is a presumed relationship between the diasporic community and the land which they left and to which the possibility of return always subsists, or what we are apt to term as 'imaginary homelands', 'motherland', or 'home'. Amitav Ghosh (1956 _), a major writer on the theme, is concerned with subjects like immigrations, exile, cultural displacement, and the stories that come out from transnational cultural flows. His second novel, The Shadow Lines (1988), is a work on diaspora, nationalism, freedom, imagination, ideology, and their inevitable consequences. In 'The Shadow Lines: A Note', G.R Taneza addresses the novel as 'an eloquent critique of colonial hangover and cultural dislocation in postcolonial situation as also the psychological make-up of the contemporary man who thrives on violence' (149 -50). It deals with the issue of geographical fluidity and cultural dislocations with a new sense of consciousness and firm grasp of socio-cultural and historical matter. Fakrul Alam, in his seminal work Imperial Entanglements and literature in English, observes that the plot of The Shadow Lines " involves people who are traveling across borders and over space ceaselessly while its unnamed narrator takes it upon himself to crisscross history and nations to chronicle the way lives intersects throughout history and across continents"(316). All the major characters of the novel are 
constantly traveling across the frontiers and intermingling despite differences in race or nationality. They keep on moving in and out of time and place for one or the other reason. It has much in it that shows continuing interest in this theme and the diasporic consciousness. Seema Bhadhury says in 'Of Shadows, Lines and Freedom: A Historical Reading of The Shadow Lines', "Ghosh's characters have to deal with two types of servility - the one is to ideas spawned by history, viz. the ideas of nationalism. These ideas hold sway even after the times to which they were relevant have passed. The other is servility to one's personal fantasies that distort one's vision, 'Tha'mma', the writer's grandma ---personifies the first type while, 'Ila', the writer's cousin personifies the second' (107). Our aim in this paper is to focus on these two major diasporic characters: Tha'mma and Ila, and highlight how they are transformed consciously or unconsciously and are being victimized by their diasporic conditions. Besides, we'll also focus on how these two characters' flawed judgment and void vision have caused tragedies not only for their own lives, but also for the lives they are related to.

Bhabha in 'Location of Culture' observes that Colonialism engenders "the unhomeliness that is the condition of extra territorial and cross-cultural initiation . . . "( 940). Here Leela Gandhi's view expressed in Post Colonial Theory, "diasporic thought finds its apotheosis in the ambivalent, transitory, culturally contaminated and borderline figure of the exile, caught in a historical limbo between home and the world"(132) is also particularly relevant. This unhomeliness is the pernicious fact that haunts the life of both Tha'mma and Ila, since neither of the two has a real home other than the constructed one for the former and the neglected one for the latter. 
Born in Dhaka in 1902, part of the pre-partitioned Indian Subcontinent, Tha'mma, the unnamed narrator's grand mother, has lost her home forever when she first left the place with her husband for Mayanmar, his working place. She passed her childhood in 'a big joint family, with everyone living and eating together' (SL 121). As her Jethamoshai says, "Once you start moving you never stop" (SL 215), so it happens to her. After her husband's death, she moves to Calcutta, which was then un-partitioned. Once the partition of India takes place her sense of 'home' begins to be problematic. When she comes back to Dhaka on $3^{\text {rd }}$ January, 1964, she asks, 'Where is Dhaka? I can't see Dhaka' (SL 193). Since, due to the partition, her place of birth [Dhaka] had come to be so messily at odds with her nationality (SL 152) as an Indian. At the Dhaka airport, Tridib takes the opportunity to throw a ground-breaking comment on her: "But, you are a foreigner now, you're as foreign here as May_ much more than May, for look at her, she does not even need a visa to come here" (SL 195). Shawkat Hussain points in his essay 'PostColonial Angst in Amitav Ghosh's The Shadow Lines', "perhaps the greatest irony of independence of India for characters like Tha'mma is that while it gave them freedom and a new nation-state, the Partition took away their "homes" and the dialects that gave them their special identity" (127). Tha'mma shares the anxiety and angst of migrancy suffered by thousand of other Hindus who left the East Bengale, populated by the Muslim-majority. Her longing for her Dhakaeit dialect, finds way when Maya, her younger sister, comes to Calcutta. As soon as they meet, Tha'mma hurries towards Maya, embraces her, "laughing, talking quickly in that language that none of us could understand properly, their old Dhaka dialect'”(SL 40).To understand Tha'mma's character, which Tridib calls 'a modern middle-class woman', the following comment by him is worth mentioning: 


\begin{abstract}
"All she wanted was a middle- class life in which, like the middle classes the world over, she would thrive believing in the unity of the nationhood and territory, of self-respect and national power: that was all she wanted_a modern middle class life, a small thing that history had denied her in its fullness and for which she could never forgive it" (SL78).
\end{abstract}

On the other hand, the globe- trotting Ila's diasporic dislocation frees her from any essential idea of home. Bill Ashcroft et al's comment made in The Empire Writes Back is worth-mentioning here "Diaspora does not simply refer to geographical dispersal but also to the vexed questions of identity, memory and home which such displacement produces" (217-218). She says while playing with the narrator, 'We can choose to build a house wherever we like' (SL 70). She does not possess the migrant sensibility struggling to find accommodation and alliterations, but a rootless, careless one. She neither repents the absence of the idea of home in her life, nor bothers to find any alternative. Time and again, the narrator says: "I could not persuade her that place does not merely exist, that it has to be invented in one's imagination" (SL 21). In this regard, we can add what Tridib says about her, "although she had lived in many places, she had never traveled at all" (SL 21). This proves how Ila's constant movements have robbed her of her imagination and curiosity. She stands sharp in contrast to the narrator who says, ' Tridib had given me worlds to travel in and he had given me eyes to see them' (SL 20).

The concept of freedom is completely different for Tha'mma and Ila. The two polar characters are obsessed with the idea of freedom. For Tha'mma, the dangerously nationalist, freedom means liberation of her nation from the colonizer British as well as defeat of their enemy 
i.e. Pakistan. She told Tridib about the terrorist movement amongst nationalists in Bengal in the first few decades of this century "about secret terrorist societies like Anushilan and Jugantor and all their offshoots, their clandestine networks, and the home-made bombs with which they tried to assassinate British official and policemen" (SL 37). We know how she treasures the memory of her shybearded class-mate who was a member of the terrorist movement amongst the nationalists in Bengal, how she worships Khudiram Bose and Bagha Jatin, the martyrs. To the narrator she expresses her secret will to do anything to be independent of the colony. She says, "It was for our freedom: I would have done anything to be free" (SL 39). Even after partition, there begins a war between India and Pakistan in 1965 and she donates her gold chain, the last relic of her for her husband to the war fund. She says to the narrator that she parts with her cherished relic 'For Your sake; for your freedom' (SL 237). Tha'mma, the fiercely bourgeois old lady, with her imagination enslaved to the ravaging idea of stark nationalism, sinks into continual dementia and lives more in her imaginary world than the real one, to which the unnamed narrator, his mentor Tridib and his beloved May Price belong. She believes in violence as a means of freedom or liberty. Her attitude can be explained in the light of what Frantz Fanon wants to establish in both The Wretched of the Earth and Black Skin, White Masks, that the colonized is doomed to be a mere reflection of his master ( located in the imaginary ), or he must fight his master through active struggle. Surely Tha'mma believes in the latter way.

But, for Ila, freedom means something radically different. When at the Grand Hotel she wants to dance and Roby protests saying "you can do what you like in England. But here there are certain things you cannot do" (SL 88). Ila bursts out in rage and shouts: "Do you 
see now why I've chosen to live in London? Do you see? It's only because I want to be free" (SL 88). When the narrator asks, 'Free of what?' She replies: "Free of you!Free of your bloody culture and free of all of you" (SL 89). Then the narrator shouts back: "You can never be free of me, I shouted through the open window. If I were to die tomorrow you would not be free of me. You cannot be free of me because I am within you. . .Just as you are within me" (SL 89).

If Tha'mma stands for extreme nationalism Ila represents, undoubtedly, pervert internationalism. Ila has traveled all over the world with her parents, as Urbashi Barat observes in 'Imagination and Reality in The Shadow Lines', too great an exposure to reality has erased the magic from her eyes, so that all those places on the maps which are to the narrator ' a set of magical talismans' are for her merely familiar, commonplace, dull, significant only by virtue of the position of Ladies toilets in the airport lounges, which become for her the signs of stability, 'the only fixed points in the shifting landscape of her childhood'(20). To her Cairo was 'a place to piss in' and the London Underground was 'merely a means of shifting venue'. Therefore it is no surprise that she would be irritated by the narrator's enthusiasm for the Underground. Whatever city she happened to be living is caught in her ever changing Yearbooks of the international schools which are full of photographs only. As if she never lived a place but: "The places themselves went past her in an illusory whirl of movement, like those studio screens in old films which flash past the windows of speeding cars" (SL 23).

However, here we see, both Tha'mma and Ila want to be free but their conception of freedom is shaped by the place they live (Or do not live) the time they go through (or do not bother to go). Bill Ashcroft, Griffiths and Tiffin write in Key Concepts in Post-Colonial studies "The development of diasporic cultures necessarily questions 
essentialist models, interrogating the ideology of a unfitted, natural, cultural norm" (70). The opinion justifies some of Ila's assault on the cultural norm of India. Ila is not the Indian Woman in her naïve appearance and trembling attitudes with the vermillion dot on her forehead. Thamma compares Ila's short hair with the 'bristles on a toothbrush'. With her 'tight trousers' Ila, for Thamma; seems to be 'a free school street whore.' Actually Ila, does not stand anywhere, her diasporic condition masks her real identity. She is like Magda grown up in the basement of history, representing her experience of racial harassment. It (the Magda story) also manifests her transformations, her golden hair, her deep blue eyes reflecting her subconscious racial anxieties behind her confident facade.

Memory plays a crucial part in The Shadow Lines. Almost all the characters live in some stories, as we hear Tridib saying to the narrator: "Everyone lives in a story, he says, my grandmother, my father, his father, Lenin, Einstein, and lots of other names I hadn't heard of; they all lived in stories, because stories are all there are to live in, it was just a question of which one you chose. . . ."(SL 182).

These stories serve for both 'Tha'mma and Ila an escape from the harsher realities of life. We see how 'Tha'mma invented stories about their 'upside down' house to make little Maya sleep. Her idea of name as well as her idea of Dhaka is a construct, preserved in her memory. Dhaka, for her, is a cluster of images: Cham-Chams, fish, Dhakai saree, so on. That is why when she steps on Dhaka the first question she asks is "where's Dhaka ? I can't see Dhaka" (SL 193). The narrator understands very well that, "her Dhaka had long since vanished into the past' (SL 193) but the old lady keeps on hanging around her old memory unless it creates a mess. The narrator realizes very well that his grand mother and the people like her 'who have no home but in memory learn to be very skilled in the art 
of recollection' (SL 194). Tha'mma's dislocated past; reconstructed memory and illusory desire lead to three unnecessary deaths. Since she lives in the past she does not pay any heed to Shaheb's precautions and prohibitions about Dhaka's present condition. Niaz Zaman points in A Divided Legacy, "Grand mother's past is a figment of her imagination. The loving uncle she is going to rescue doesn't want to be rescued and never was loving, and, in an attempt to meddle with other people's lives and rectify lapses in the past, Grandmother succeeds only in bringing about the deaths of three people" (314). Therefore, we realize how Tha'mma's misleading memory and desires result only into the deaths of three people. Moreover it is from May's memory that we come to know that the Grandmother who had talked about freedom and sacrifice was quite willing to leave the old man to his fate!

Tha'mma's diasporic dislocation makes her self-contradictory as well. We are told by the narrator that she hates nostalgia and preaches to him that nostalgia is a weakness a waste of time that it is everyone's duty to forget the past and look ahead and get on with building the future (SL 208). But, it is she herself who declares "The past is what we talk about" (SL 127). This contradiction is nothing but the by-product of her position as a diasporic person.

Ila, of whom we are informed that, 'for Ila the current was the real' (SL 30) and once she herself claims that "I am free" (SL 32) too invents stories. While playing Houses, she makes stories, creates roles and urges the narrator to 'pretend'. The Magda story is the sub-conscious reconstruction of her own experience of racial antagonism at London where Nick didn't want to be seen with her. Once again, when she scolds the narrator as 'third-world tapioca farmer', unconsciously Ila locates herself out of the third world. Ironically enough, she does not belong to the first-world as well. 
Her real location is always in flux. Therefore, we see how sharply she also carries the self-contradictory traits in her personality. Though she shits on Bengali/Indian culture she treats the narrator and Roby in her favorite Indian restaurant (Maharaja) in a small Bangladeshi place in Clapham.

Both Tha'mma and Ila have illusions about their identities. Tha'mma does not accept that she is a 'refugee' on the ground that she comes to Calcutta before partition. She jeopardizes her identity with her idea of freedom and nationality and in the end, proves herself a misfit to the newer world. She fails to cope with the idea that shadow lines or geographical boundaries cannot bring one's true or real identity. Actually, identity is a continuous process and for Tha'mma the procedure has been hampered and distorted by her memory, desire and reality. We can say The Shadow Lines is a book of Tha'mma's quest for her true or real identity. The naming of the two major divisions of the book 'Going Away' and 'Coming Home' ironically refers to her psychological journey and reinforces the fact. Tha'mma's personal life shrinks from the abundance of the 'big house' into a tiny little flat of South Calcutta, and her sense of self respect hinders herself to be lost in rhizome and that compels her to continue herself searching journey up to the last moment of her life. Her prolonged story of the past and the continuous changes of the present historical facts made a perpetual clash in identifying herself. She made the major mistakes of her life knowingly or unknowingly out of this psychological trauma. This establishes her as a diasporic character dangling at the quirk of history. Once she comments about Tridib that he wastes his time and wasted time stinks. Ironically it's her time that rots and stinks.

When the narrator shares with 'Tha'mma' the story of Ila's being harassed by racial antagonists in London the old lady realizes the 
fact and says: "It was Ila's fault. It was her own fault, and Maya's fault and fault of that half-witted mother of hers. It was bound to happen. She has no right to be there. She doesn't belong there"'(77). Tha'mma, and with her, we realize that if Ila would stay at Calcutta she could lead a princess's life but her choice of London and the consequences of this dislocation is responsible for her being victimized by the racial antagonists. But Tha'mma's second assumption about Ila's living in London is defendable. When the narrator describes to his grandmother the incident at Grand Hotel and explains to her why Ila' has preferred to live in London that is 'to be free', 'Tha'mma' throws away the remark that Ila has chosen London since it allows her to lead the life of 'a free school street whore'. But we see, Ila has never had that kind of amoral intension. We find her only with Nick. She herself says the narrator: "I'm about as chaste, in my own way, as any woman you'll ever meet" (SL 188).

Ila, who once brags, "I Ila Datta Chaudhury, free woman and free spirit (SL 187)" is nothing but a person for whom maps and memory are irrelevant. Meenakshi Mukherjee in her essay 'Maps and Mirrors' has found something very noteworthy in little Ila's playing House. Her house has no veranda. When the narrator points "It can't be a real house. . because it does not have a veranda, she opposes "what shall we do with a veranda?'" (SL70) Mukharjee thinks terraces and verandas, like courtyards, are essentially female spaces in our (Indian) culture and Ila's inability to comprehend their importance can be attributed to her cosmopolitan and diasporic disposition. Ila's English House and English family with an imaginary English child with an English name are easily explainable under the light of Gramsci's idea of hegemony. Shelley Walia observes in Postmodern Encounters: Edward Said and the Writing of History, "Gramsci's idea of hegemony links the spontaneous consent 
of the masses to the maintenance of power by a minority class through the use of persuasion and collaboration" (31). We see how Ila's grand father is called 'Shaheb' by the family members, here it has become a family joke that 'his hat wouldn't come off his head (SL 34). We are also told how Ila's mother's eccentric Euro-centricity has earned her the title of Queen Victoria. What is Ila but the product of the hegemonised Shaheb's and Queen Victorian's erroneous upbringing!

Kaushlesh Biyani points in an online essay 'Shadow Lines' " the author embodies the ideas of western nationalism and the denial of history to the third world through the narrator's 'white -washed' cousin Ila (4)". There is no point in denying Biyani when he writes that through Ila, Ghosh aims at challenging the western orientation of history---- a history written by the victors---- not necessarily the true one. When Ila tells the narrator 'nothing really important ever happens where you are', she articulates the western disregard for eastern or third world---- an attitude about which Said writes in his groundbreaking book Orientalism. Here Said makes the claim that the whole of Western European and American /Occidental scholarship, literature, and cultural representation and stereotype creates and reinforces prejudice against non-western cultures, putting them in the classification of oriental (or others). Said asserts that according to the Occidentals, the Orientals had no history or culture independent of their colonial master. The reason behind Ila's this kind of prejudice is clear in Franz Fanon's following comment from The Wretched of the Earth that "Colonization is not satisfied merely with holding a people in its grip and emptying the native's brain of all form and content. By a kind of perverted logic, it turns to the past of oppressed people, and distorts, disfigures and destroys it" (170). 
However, we cannot but admire Ila for one trait, she hates kitsch or hypocrisy. Though her nature is full of 'the signs of cosmopolitanism' she is not hypocrite like 'Tha'mma whose sentimental love for Jethamoshai disappears in the moment of survival. When at the Grand Hotel she offers Roby and the narrator to take beer Roby denies on the ground that he can do this in his college but not in the place where he lives and is known. At this she shouts at him "you are a little hypocrite" (SL 52). Of her moral judgment we are also given some information. Ghosh writes: "She could understand and admire someone who never ate meat on principle, but a person who was a vegetarian only at home was, to her, the worst kind of hypocrite" (SL 82). On this ground Ila is much more down to earth and admirable than Tha'mma whose sentimental ways fly away in the moment of crisis.

One interesting point is that, though diasporic movement has affected the life of both Tha'mma and Ila, and these two characters stand in stark opposition to each other they are ironically identifiable. For several times, the narrator emphasizes the resemblance of characters, especially of physical appearance. Tha'mma finds in Roby her own replica and insists that the narrator should be like him. But the narrator thinks he resembles Tridib not Roby (or grandmother). Humorously enough, we are informed that the narrator resembles Ila (grandmother's Other). Therefore, there becomes an unconscious bondage between the characters that either resemble each other or want to, which brings all of them 'Tha'mma, Tridib, Roby, Ila and the narrator under the same umbrella of mixed/confused identification. There is another major point where 'Tha'mma and Ila are identifiable; on the point of their loving someone or being loved by. We know of 'Tha'mma's ideal hero, the shy bearded classmate who has been executed for being a member 
of secret anti-Britain movement and how she regrets for not knowing him from earlier. We also notice her secret brooding over how handsome he was and so on. It's romantic, as much as Ila's love for Nick. As was Tridib obsessed with his love for a woman across the sea; so was Ila taken by a man across the sea. Even the narrator's love for Ila is also romantic in the sense that for him Ila is also the woman across the sea. This theme of romantic love for person across the sea or unattainable again brings the major characters under the same umbrella and makes 'Tha'mma, Tridib, May, Ila, Nick and the narrator identical to each other.

The Shadow Lines exhibits multivalent diaspora and dislocation creating multi -dimensional consequences. The book includes professional, academic, tourist, forced, unconscious, habitual migrancies. Shaheb's and Ila's father's movements are profession, the narrator's visit to London is academic, May's visit to Calcutta is a romantic tour, Ila's childhood migrancy and movement are forced and her movement after being adult is habitual. Therefore, almost all the characters and happenings of the novel are somehow related to the idea of diaspora and its consequences. In this paper we have tried to focus on how the personae of 'Tha'mma and Ila are shaped, deluded, affected by diaspora and dislocation. What is interesting is that Ghosh to the end of the novel continues to survey the migratory cross -cultural complexity of modern society. One of the reasons why The Shadow Lines is so pivotal to an understanding of Diaspora literature is that it focuses on the both ends of diasporic situation: blind nationalism in Thamma and Ila's cold-eyed detachment from the need for a root. In presenting the complexities of personal and social interactions between the characters, Ghosh does not forget to question the very authenticity of nationalism, the vain validity of violence and the legacy of maps and margins. 


\section{Works Cited}

Alam, Fakrul. Imperial Entanglements and Literature in English. Dhaka: writers.ink, 2007.

Bill Ashcroft, Gareth Griffiths and Helen Tiffin. Key concepts in Post colonial Studies. London: Routledge, 2004.

---. The Empire Writes Back._London: Routledge, 2002.

Biyani, Kaushlesh. "Nationalism and Displacement in the Indian Diaspora." 15 September 2004. Kaushlesh Biyani's Website. 15 December 2007. <http://www.biyani.com/downloads/work/Ans372_ShadowLines.p df $>$.

Dhawan, R.K., ed. The Novels of Amitav Ghosh. New Delhi: Prestige, 1999.

Fanon, Frantz. The Wretched of the Earth. London: Penguin, 2001.

Gandhi, Leela. Postcolonial Theory: A Critical Introduction. New Delhi: Oxford UP, 1998.

Ghosh, Amitav. The Shadow Lines. New Delhi: Oxford UP, 1999.

Hussain, Shawkat, 'Post-Colonial Angst in Amitav Ghosh's The Shadow Lines.' Colonial and Post Colonial Encounters, ed. Zaman, Azim \& Hussain. Dhaka: The University Press Limited, 1999.

Rivkin, Julie and Michael Ryan. Literary Theory: An anthology. Oxford:

Blackwell, 1998.

Walia, Shellay. Postmodern Encounters: Edward said and the Writing of History. UK: Icon Books, 2001.

'Diaspora', Wikipedia the Free Encyclopedia.2001.15 December 2007.

< http://en.wikipedia.org/wiki/Diaspora>

Zaman, Niaz. A Divided Legacy. Dhaka: The University Press Limited, 1999. 